\title{
Factors Impact on Religious Tourism Market: The Case of the Palestinian Territories
}

\author{
Jafar Subhi Hardan Suleiman \\ School of Housing, Building and Planning, Universiti Sains Malaysia, Malaysia \\ E-mail: abahre2006@yahoo.com \\ Badaruddin Mohamed \\ School of Housing, Building and Planning, Universiti Sains Malaysia, Malaysia \\ E-mail: bada@usm.my
}

Received: September 6, $2010 \quad$ Accepted: October 10, $2010 \quad$ doi:10.5539/ijbm.v6n7p254

\begin{abstract}
Palestine, the home of the world's three major religions: Islam, Judaism, and Christianity. Hence, is considered as the first center of tourism due to the coming of these three major world faiths flocking to Palestine to engage in sacred pilgrimages. Some of these sites which are frequently visited are Jerusalem, Nazareth, Jericho, Bethlehem and Hebron. Palestine was for many centuries a destination of pilgrims and visitors of Muslims and Christians from all over the world. Unfortunately, Palestine after the 1948 War fell under the Israeli Occupation and was exposed to many catastrophes up until this time; all this led to the instability and the decrease in the number of tourists to Palestine; which had become a dangerous area which reduced the flow of tourism in general. At the same time, came the peace negotiations between the PLO (Palestinian liberation organization) and Israel in Oslo which was signed in Washington in 1993. In this period there was an economic recovery and tourism in the Palestinian Territories, especially in the West Bank and Gaza Strip started to once again flourish. The Primary purpose of this paper is to show the significance of the religious tourism in Palestine and influence of conflict on Palestinian tourism; also indicated which factors impacts on Palestinian tourism as well.

This paper concludes that Palestine is unique, due to its history, heritage, culture, geographic location, environment and religions. This study suggests to the Ministry of Tourism and Antiquities in Palestine to create new forms to protect the Islamic and Christian places in Palestine as well as to encourage more tourists to visit. Peace is considered as a vital strategy for enhancing the Palestinian tourism industry.
\end{abstract}

Keywords: Palestine, History, Religious tourism, War, Political instability, Peace

\section{Introduction}

Palestine is located in the heart of the Middle East and lies upon the southwest of Asia on the east of the Mediterranean basin. The site has a significant and strategic location through which links Asia with Africa and the Mediterranean Sea (Al-Rimmawi, 2003). While, the climate is pleasant because it has four seasons throughout the year (summer, autumn, winter and spring).

The historical area of Palestine is almost 27,000 sq km; the area of the Occupied Palestinian Territories is 6000 sq km, which portion of it controls by the Palestinian National Authority, which includes the West Bank and Gaza Strip (Al-Rimmawi, 2003).

Although Palestine is not generally recognized as an independent state, Palestinian Arabs have been working self-rule as establish a Palestinian state separate from Israel for several decades (Healey, 2009; Pattullo \& Minelli, 2006; Sauders, 2008). Nevertheless, conflicts over land have prohibited a peaceful resolution and prevented to establish a Palestinian state over the areas that occupied by Israel in 1967 (United Nation, 2009). The Primary purpose of this paper is to show the significance of the religious tourism in Palestine and influence of conflict on Palestinian tourism; also indicated which factors impacts on the Palestinian tourism as well.

\section{History of Palestine}

The history of Palestine is refers to the (Lower Paleolithic era) Tel Ubeidiya which is located near the Jordon valley, this site proves that (Homo erectus) existed in Palestine therefore; many ancient races resided there, the Canaanites undoubtedly were the first people to live in land of Palestine and the first to establish a civilization in it, in the same period, arriving in Palestine were the philistines who integrated and mixed with the original people according to Alternative Tourism Group (ATG, 2005). 
In modern history, Palestine over the years has been subjected to many disasters and tragedies, in the year 1948 (The Catastrophe), the Jewish Zionists Occupied Palestinian cities and destroyed homes and committed numerous massacres in Palestinian cities and villages and the displacement scattered many of the people of Palestine to various areas, and even outside Palestine to the neighboring countries. In the year 1967 The Tragedy of the Zionist Jewish occupation of the West Bank and Gaza Strip, in the year 1987 was witnessed the start of the first intifada against the Israeli Occupation (ATG, 2005; Giacaman et al., 2009; UN, 2009)

Then, came the peace negotiations between the Palestinian Liberation Organization (PLO) and the Israeli government in Oslo which signed this agreement in Washington in 1993, the Oslo accords on September, 1995 divided the West Bank in areas; Area A, Area B and Area C (Shahin, 2007). The second Intifada" began in September 2000 because of Ariel Sharon's visit to "Al-Aqsa or al Haram al-Sharif "which was a provocation to the Palestinian people and the entire Islamic world. After that, all cities in the West Bank and Gaza Strip were subjected to the repression of the Israeli army in the form of killing and suppression of Palestinian demonstrations until Israeli bulldozers and tanks demolished houses and committed massacres against the Palestinian people (Giacaman et al., 2009). In fact, because of that, Israel destroyed the infrastructure and superstructure of the Palestinian Territories and increased the poverty rate for families in the Palestinian territories by $65.8 \%$ (Palestinian Central Bureau Statistics, 2006).

\section{An Overview the Palestinian Tourism Industry}

Palestine has a lot of historical and religious places. The reason for this is the fact that Palestine is known to be "The holy land". Without doubt, these numerous features are unique and made it as a significant destination for tourists from all over the world. The most well-known towns in Palestine are Bethlehem and Jerusalem and almost all international tourists' stopover at both areas and spend more time because of their religious importance (Al-Rimmawi, 2003; Sizer, 1999; Isaac, 2010). At the same time, they have lots of natural resources. For instance, Jerusalem is considered the main host for three monotheistic religions. As reported by Abu Rabah (1998), the future economic development of Palestine depends on the tourism industry.

Khano et al. (1997) reported that Palestine has multitudes of archeological, cultural, religious, natural and historical resources. These characteristics enable Palestine to be a major tourist destination from all over the world. In the past years, Palestine appealed to a lot of pilgrims, due to the diversity of believers in this area. On the other hand, they demonstrated that this uniqueness will back up the Palestinian economy supported from tourist's accommodations, transportations, facilities and services. Due to availability of attraction elements in Palestine, it can play a major role in tourism and make it uniqueness in the world. These features were available since the middle of nineteenth century and are divided into five types; cultural \& physical, religious, historical \& geographical, diplomatic \& political and scientific (Cohen-Hattab \& Katz, 2001).

\section{Significance of Religious Tourism in Palestine}

Palestine plays vital an important and role in attracting and motivating the tourists whom find interest in religions, history, cultures, traditions and environment. Palestine is sacred for the three monotheistic world religions: Islam, Christianity and Judaism. In addition, it is a holy place for Muslims due to it being home to prophets such as Ibrahim (Abraham), Zakaiyya, Isa (Jesus), Suleiman (Solomon), David (Dawoud), Joseph (Yusuf), Jacob (Yaqoub). There are a lot of places that feature diverse tourist importance to the world through ancient cities.

Jerusalem is the basic hub and key for tourism and pilgrimage in Palestine, the first destination for those who visit Palestine, (See Figure1) sacred and spiritual for Muslims through al Aqsa Mosque (Far Mosque)

In regards to the Christian religious sites of Jerusalem, these places are regarded as the most important in the world containing various churches and monasteries of the Christian religion such as The Church of Holy Sepulcher (PACE, 1999; Shahin, 2007). As Jerusalem is a unique place and major consideration in religious tourism, there are a lot of villages, districts and towns considered sacred which attract tourists and pilgrims to visit and stopover in them such as Hebron, Bethlehem, Jericho, Nazareth and Nablus.

ATG (2005) presented the religious and historical significance of Bethlehem town dating back to the fourteenth century BC this city is mentioned in the Amarna letters, and also mentioned in the bible. The city called it Lehmo in the Canaanite period which meant the god of fertility for them, for many centuries pilgrims were visiting it and some of them were of nobility and Patriarchs such as, the mother of the Emperor, Constantine 'Queen Hilana', She requested from her son to build the Church of the Nativity, which was built on the holy cave of Jesus. In the period of Caliph's "Omar Bin Al Khattab" he visited this town and then there is his mosque near the nativity church which is a sign of the freedom of religious property of the Christians.

The town of Jericho at the crossing between Jordan and Palestine, has the (Allenby crossing), which is the only access for residents of the West Bank to visit neighboring countries and the nations of the world via Jordan. Jericho is an important city for tourism through a variety of tourist attractions in it, and its considered the town for winter vacation for the Palestinian people, because of its warmth in winter season and also for having the best dates, citrus fruits and bananas in the world, the ancient town of Jericho has been associated with ancient walls, (oldest city in the world, which dates back to 10,000 B.C) as well as having a lot of historical and religious sites 
(PECDAR, 2001). Table 1. shows the number of Palestinian tourist accommodation and tourism including rooms and beds which are available currently in the Palestine. Therefore, according to the Palestinian Central Bureau of Statistics (PCBS), the hotels survey, annual reports 2010 by the numbers of guests in the year of 2000 were 316,949 , whilst in 2009 were 452,625 persons.

\section{Political Instability and Tourism}

\subsection{Impact of Political Instability on Tourism in the World}

Goeldner and Ritchie (2006) showed that the tourism industry plays a vital role in the economy for all of the countries of the world, providing employment, incomes, taxes revenues and foreign exchange. All of these features come from visitors when visiting the destinations, whereas the visitors will play a role in the income of the economics and increasing the GDP. At the same time, these benefits would not be achieved without political stability. There are a lot of things which affect tourist destinations such as wars, conflicts, crises, terrorism and SARS.

Political instability related with tourism can have very negative effects on tourism destinations that will result in the decline of the number of tourists who visit the destinations and also will bring negative effect to the tourism industry because tourism is a sensitive and a volatile industry and all of these effects from political instability such as armed attacks, civil wars, bombings, attacks on tourists, wars, change in government, threat of war with another country, which will deter or obstruct the image of the destination through media reporting and government policies and even word of mouth reporting (Seddighi et al., 2001).

Page and Connell (2006) argued that the impact of instability can have direct impact on tourism and negative images about the destinations will travel to tourists by word of mouth, government policies and media at the same time these tools of impact will convert the trend of behavior travel for them as well as lead to the decline in the number of visitors, the authors explained these influenced through political turmoil upon tourism in some countries (e.g. Fiji, China, Tibet Spain, Peru and Northern Ireland).

A study by Altinay and Brown (2006) suggested that tourism production in Cyprus can be the greatest through an economic environment and a stable politics. At the same time, unstable politics threatens tourism in Cyprus and also the neighboring countries particularly, Turkey and Greece. In the other side, both the Gulf conflict in 1990 and the Turkish foray in 1974 were affected by the number of foreign visitors. Therefore, there was an increase in the problems and downturns in these economies. In another issue when the war in Croatia began in 1991 there was a decline almost 5 billion US Dollars in GDP only from tourism caused by the effects of the war and crisis, nevertheless declined the number of visitors to Croatia approximately $75 \%$ and the spending in tourism sector arrived to $77 \%$ a decline (Currie et al., 2004).

\subsection{Impact of Conflict on Palestinian Tourism}

This part focuses on the challenges facing tourism industry in Palestine, especially West Bank and Gaza strip. Some researchers have discussed the Israelis' offensive actions against Palestinian tourism sector (Khano et al., 1997; Sizer, 1999; Al-Rimmawi, 2003; ATG, 2005; Issac, 2010). They have also focused on the inbound tourism and pilgrim's journeys, coming into Palestine and staying for few hours only. This is because of the negative media report presented by Israeli campaigns associated with Israeli tour operators, who dominates tourism sector in Palestine. As a result, these unethical actions mislead numerous international tourists and form a false image about Palestine whereas tourists imagining it as dangerous and unsecured place. This caused a great decrease in tourist numbers. Other obstacles challenging tourism in major Palestinian tourism places are the shortage in services and facilities, which are supposed to be provided by the Palestinian tourism ministry in collaboration with private investors.

In the last several decades, scientists have observed Palestinian tourism changes (Al-Rimmawi, 2003; Al-Bandak, 2005; Isaac, 2010). They have discussed the main factors affecting such traveling. Political, financial, infrastructure and other factors were studied in order to overcome these difficulties. These factors are:

\subsubsection{Factors Related to Political Obstacles}

Most researchers agree on a fact that the main barrier to Palestinian tourism is the political factors, represented by Israeli occupation (Sizer, 1999; ATG, 2005; Hammad \& Hammad, 2008; Isaac, 2010; Pattullo \& Minelli, 2006). It was stated by Sizer (1999) who worked as Briton tourist operator, that difficulties face UK travelers. Sizer listed plenty of ethical matters encountered by tour operators, pilgrims and their leaders. He also discussed some actions needed to be taken by tour operators and pilgrims to solve such problems. Figure 2. demonstrates the number of visitors arrivals to the Palestinian Territories that was unstable due to the Israeli-Palestinian conflict.

As reported by Al-Khawaja (1997), policies which are applied by Israeli authorities on foreign tourists during their visit to Palestine, especially Bethlehem town affect travels. One of the policies is by preventing tourists from spending more than one hour in local church and shopping. The effect of this is that Israeli authorities dominate transportations, accommodations, other facilities and services in the whole of Palestine. As stated by 
Al-Khawaja, when comparing the revenue of tourism among the Palestinians and Israeli, inequality is found. This he proved by indicating that $85 \%$ of tourism revenue heads to Israel.

In 2005, a report was published by WTO pointed out the tourism situation in the Palestinian territory as follows: tourism enterprises and hotels in East Jerusalem have their special problems. These problems include the Israeli control of cities, which enables them to oblige regulations against Palestinian hotels. Therefore, tourism sector in East Jerusalem has many troubles which do not exist in West Bank and Gaza Strip, that includes: 1) "Arnona Tax" imposed compulsory by Israeli government on property in Jerusalem and it depends on location and size. Hotels in East Jerusalem has many restrictions on mobility, although, West Jerusalem has freedom of mobility and has benefits from domestic tourism and level business. 2) Tourism services and accommodations in East Jerusalem submitted to Israeli a labor law that is restrictive. This leads to the decline in economy of tourism industry in east Jerusalem. 3) Construction or extensions of new hotels in east Jerusalem are restricted because the Israeli does not allow such actions, although, these restrictions do not exist in West Jerusalem. 4) Israel imposes constraints of mobility on Palestinian workers coming from West Bank to works in east Jerusalem. 5) Strong competition facing the hotels in east Jerusalem. Israeli hotels offer modern products at similar room rate to east Jerusalem, while the buildings of east Jerusalem are old and not modern.

After the breakdown of peace process in September 2000, a great effect on Palestinian economy was observed. In fact, the economic situation in West Bank and Gaza became difficult and critical because of restrictions, roadblocks and separation barriers that limits workers, services as well as goods. As a result, a great increase in poverty rate among Palestinians at both parts was noticed (Hara, 2004). Similarly, Al-Rimmawi (2003) revealed those obstacles that are ideologically or physically. These barriers deterred the Palestine tourists at the period of peace between Palestinian and Israeli authorities. Despite the establishment of peace, international tourism in Palestine is still dominated by Israeli authorities. In addition, the absence of international tourists into Palestinian parks such as Al-Badan Park was due to the same reasons. In addition, the conflict impacts on the Palestinian tourism by seizing the Palestinian tourism industry like flights, journey into the country, accommodation, flow of foreign tourists and visa issuing. Extremely, these constraints have impact on the Palestinian tourism objectives.

\subsubsection{Factors related to Financial}

Financial factor has lack of small budgets to promote tourism industry in the Palestinian Territories. As reported by WTO (2005) that budget of Ministry of Tourism and Antiquates (MOTA) is not adequately distributed. For example, most money generated goes to staff salaries without spending any amount on essential equipments such as marketing, new materials, computers, telephone lines and internet access. Moreover, due to economy of Palestine is annexed to Israeli economy; Palestine is one of the top highly priced in the region in these categories (food prices, room rates, car rental and taxes (Khano et al., 1997; Al-Rimmawi, 2003). For this reason, it is causing a negative impact on the tourism and economy sector. The hospitality service in Palestine is becoming a well-known quite expensive (Khano et al., 1997; ATG, 2005; Isaac, 2010).

\subsubsection{Factors related to Environmental and Health}

In terms of health and environmental issues in Palestine, these factors have weakness and the general appeal of Palestine to be unsatisfactory due to poor cleanliness and also inadequate attention given to the environmental issues such as unawareness of nature protection, disposal and garbage and high pollution that emitted from cars and factories results causing health problems to Palestinian people and tourists. Khano et al. (1997) emphasized that the sewerage services are fairly poor and lack modern systems and WTO (2005) noticed for poor of toilets facilities in the public areas.

\subsubsection{Factors Related to Tourism Ministry and Marketing}

Tourism ministry in Palestine is lacking of human resources trainees and experience. They lack formal training, particularly in the Palestinian tourism and antiquities ministry. A shortage of senior staff is also noticed (WTO, 2005). In addition to this, it was advised for the Palestinian tourism system to obtain a new formal legal framework structure along with upgrading. Palestinian hotel classification system was used in the previous Jordanian system with no improvement added. New laws need to be established which leads the ministry of tourism and antiquities in taking responsibilities with private and public sector in tourism. Also, Ministry of tourism and antiques in Palestine failed to implement their responsibilities for tourism sector.

On the other hand, it lacks the internal structures in committees which assist in forming new policies and decisions. The WTO (2005) reported that ministry of tourism and antiquities in Palestine lacks of these as below:

a) Official web site for the Palestinian ministry of tourism and antiques is out dated.

b) Official Policy for tourism in Palestine is not well established which leads to constraints in future investment and development.

c) Inadequate cooperation and coordination among stakeholders. This means that little coordination is present between both tourism sectors; public and private. In addition to the neglecting of the views and experiences of private sectors in tourism; such as the Arab tourist \& travel agent associations and the Arab hotel association. 
d) Investment opportunities are not identified in the ministry's' agenda. At the same time, there is a lack of tourism sector for incentive investments.

e) The condition in Palestinian hotels is very poor. Hotel sector needs restoration, maintenance and renovation after the five years intifada.

f) Palestinian tourism police is insufficient.

\subsubsection{Factors related to Facilities and Services}

According to Al-Rimmawi (2003), the lack of tourism facilities in Palestinian villages were the main factors discouraging visitors to travel to Wade Al-Badan parks. Infrastructure such as electricity, sewage, traffic congestion and other facilities are not present in that area. Absolutely, as cited by Sizer (1999) tourism in Palestine needs hotels, transport services and local guides who bring economical benefits for Palestine. Abu Rabah (1998) demonstrated the challenges which face tourism sector in Palestine during the peace process between Palestinian Authority and Israel. It lacks the regulations and upgrading, which resulted in the absence of the significance of tourism. Al-Rimmawi (2003) concluded that the Palestinian tourism requires certain visitors' centers, museums, tourism zones as well as rehabilitation and restoration of the old cities. Therefore, all of these requirements indicate that Palestinian tourism needs improvement and still lacks primary elements of tourism in general.

Khano et al. (1997) reported that Hotels development in east Jerusalem and Bethlehem region have several impediments being faced, as follows:

1) The procedure of licensing is extremely difficult for investors to obtain a license to construct hotel or extension building, due to the Israeli prohibition restrictions.

2) Very high land prices in east Jerusalem because of shortage of land.

3) Size of area is small which is almost 70.5 squares kilometers and is controlled by Israel and deters any development and construction.

Bethlehem, Beit Sahour and Beit Jala suffer the following obstacles:

a) Problems of hotels in these areas are the lack of infrastructure and run-down surroundings.

b) The lack of water is considered a major obstacle to hotel development in Bethlehem.

c) Problematic categories of areas, which is divided into three areas (Area A, B and C). Area C is fully under Israel domination which is difficult for Palestinians to obtain permission to build on their own land in these areas. The cost of land in Bethlehem region is known to be very expensive. For these reasons, hotels in Bethlehem cannot develop and extend.

d) Hotels in Bethlehem city have electricity supply problem, which is occasionally put off and telephones have lack of modern systems.

Israeli ministry facilitates the guides licensed issued to Jerusalem ID holders; on the other hand, Palestinian tourists guide are not allowed enter Israel (Khano, et al., 2005). Sizer revealed that certain harmful impacts of concern are tour operators and UK Christians to sympathize with the Palestinians who are staying in the holy land, particularly the Palestinian Christian community.

Since 1967, Israel has dominated the most important religious sites in the occupied areas, which had been under rule of the Jordanian government at that time. Religious trips to the Palestinian occupied territories are managed by ministry of tourism in Israel.

In 2005, WTO discussed the situation of tourism in Jericho city. This city has two attractive places; Tell Es Sultan and Hisham's Palace. WTO revealed several shortages in tourism facilities in that city as follows: lack to café facilities, steps and walkways, directional, shelters, lighting, street access and liable interpretative signage, insufficient interpretation of individual places, no interpretation centre as well as Mosaic is not clear at floors to make visitors see it.

From another side, this study and PECDAR (2001) have found few impediments in internal Palestinian tourism industry that include: (1) Interpretive signage and way finding are deficient, tourist maps and guides lack sufficient multi-language. (2) Palestinian tourism does not have a clear tourism policy. Therefore, lack of tourism strategy which encourages travel to Palestine and global representation. (3) Failure to take care of public resources, archeological and heritage spaces through maintenance, protection and presentation. (4) Leaders in the Palestinian tourism are lacking in experience and professionalism. (5) In general, there is a lack in the hotels rating system and there are shortages in existing quality of accommodations. No policy for pricing accommodations is present. (6) Lack of developed Palestinian economy to import the merchandise which are required by the tourism sector. (7) Absence of security and safety program in tourism sector. (8) Most Palestinian establishments lack credit cards system. (9) Shortage of influential unlicensed tourism enterprises policy, which is untaxed and undisciplined and leads to a gloomy tourism economy. (10) Tourism training centers are absent in Palestine, which graduate employee and directors in tourism services and suppliers. (11) the tourist conception that areas are not safe to visit. 


\section{Conclusion}

This study concludes that Palestine is unique, for its history, heritage, culture, geographic, location, environment and religions. The tourism in Palestine is major economic sector, it presents to the tourists who are looking for a different experience of the inventory of cultural and natural heritage of Palestine as well. The results indicate that the impacts of conflict on tourism in Palestine are likely to drop from time to time. It also increase the poverty in Palestine due to the violence and loss of tourism revenues which caused a decrease visitors number and their time spent in Palestine. These impacts are the results of the Israeli occupation such as closure, curfews, checkpoints, segregation walls, sieges, assassinations, damage of environment, movement restrictions and so on. All of these impacts obstruct tourism in Palestine and also influence domestic and international tourism decisions for choice of destination.

This paper is suggest to Ministry of Tourism and Antiquities in Palestine, the universities in Palestine, associations and institutions which are related to tourism, religious and cultural heritage in Palestine, religious leaders, decisions to challenge the occupation and its impact on religious sites and tourist sites through protection of Islamic and Christian holy sites in Palestine as well as activating the studies dealing with the reality of tourism in Palestine and impact of the occupation to the destruction of the heritage and the long history of Islam and Christianity in Palestine.

Also, the study suggests to the Ministry of Tourism and Antiquities in Palestine to create alternatives forms of religious tourism by promote Islamic and Christian places in Palestine as well as to invite new tourists to visit. Peaceful resolution is playing a vital role between the Palestinians and Israelis for enhance and encourage tourism industry and open regional markets.

\section{References}

Abu-Rabah, A. (1998). Palestinain Tourism: Concepts, and Visions. Jerusalem: Al-Amal Press.

Al-Rimmawi, H. A. (2003). Palestinian tourism: a period of transition. International Journal of Contemporary Hospitality Management, 15 (2), 76-85.

Al-Bandak, Z. (2005). A strategic tourism industry response to international terrorism, crisis, and disasters. Third global summit on peace through tourism, October 2-5, Pattaya-Thailand.

Al-Khawaja, H. (1997). The current status of palestinain tourism sector and range of its response to the requirements of regional cooperation. 41-92.

Altinay, L., \& Bowen, D. (2006). Politics and tourism interface the case of cyprus. Annals of Tourism Research, 33(4), 939-956.

Alternative Tourism Group (ATG). (2005). Palestine \& Palestinians: Guidebook (1 ed.). Ramallah, Palestine.

Currie, D. M., Fellow, F., Skare, M., \& Loncar, J. (2004). The impact of War on Tourism: the case of Croatia. Paper presented at the Conference on Tourism Economics, Palma de Mallorca.

Cohen-Hattab, K., \& Katz, Y. (2001). The attraction of palestine: Tourism in the years 1850-1948. Journal of Historical Geography, 27(2), 166-177.

Goeldner, C. R., \& Ritchie, J. R. B. (2006). Tourism: Principles, practices, philosophies (10th ed.): Hoboken, N.J. John Wiley \& Sons.

Giacaman, R., Khatib, R., Shabaneh, L., Ramlawi, A., Sabri, B., \& Sabatinelli, G., et al. (2009). Health status and health services in the occupied Palestinian territory. The Lancet, 373(9666), 837-849.

Hammad, A. I., \& Hammad, S.d. I. (2008). Studies in the Palestinian Tourism and development (1 ed.). Khan Yunis-Gaza: Al-Qadsiah.

Hara, T. (2004). Estimating the econmic impacts of the tourism industrial complex on the west bank and Gaza: An analysis of the crossroads of tourism and terrorism along the road map for peace. Ithaca, NY.

Healey, C. (2009). Palestine. Our World: Palestine, 1. Retrieved from MAS Ultra - School Edition database.

Isaac, R. K. (2010). Alternative tourism: new forms of tourism in Bethlehem for the Palestinian tourism industry. Current Issues in Tourism, 13, 21-36.

Khano, M., \& Sayre, E. (1997). The Palestinian Tourism Sector: Present State and Future Prospects. Palestine Economic Policy Research Institute (MAS).

PACE. (1999). The Palestinian Assoication for cultural exchange (PACE)-Ramallah in cooperation with The Palestinain Abraham Center for Languages (PACL) -Gaza. PACE tour guide of the West Bank \& Gaza Strip "Palestine": Historical \& Archaeological Guide. Ramallah-Gaza.

Page, S. J., \& Connell, J. (2006). Tourism: A modern Synthesis (2nd ed.): Thomson Learning.

Palestinian Central Bureau of Statistics, 2007. Hotel Activities in the Palestinian Territory (Annual Bulletin-2006). Ramallah - Palestine.

Pattullo, P. with orely Minelli for tourism concern. (2006). The ethical travel guide, London, sterling, VA. First 
published. [Online] Available: http://www.pecdar.ps/index.php.

(PECDAR) Palestinian Economic Council for Development and Reconstruction in cooperation with Ministry of Tourism and Antiquities. (2001). Palestinian Tourism Development Strategy.

Sauders, R. R. (2008). Between Paralysis and Practice: Theorizing the Political Liminality of Palestinain Cultural Heritage. Journal of the World Archaeological Congress, 4(3), 471-494.

Seddighi, H. R., Nuttall, M. W., \& Theocharous, A. L. (2001). Does cultural background of tourists influence the destination choice? An empirical study with special reference to political instability. Tourism Management, 22, 181-191.

Shahin, M. (2007). Palestine A Guide (1 ed.). Ramallah-Palestine: Arab Scientific Publisher.

Sizer, S.R. (1999). The Ethical Challenges of Managing Pilgrimages to the Holy Land. International Journal of Contemporary Hospitality Management, 11(2-3), 85-90.

The United Nations. (2009). Question of Palestine. [Online] Available: http://www.un.org/Depts/dpa/ngo/history.html. (27 December 27, 2009)

WTO. (2005). Tourism Development Strategy Short-Term Action Programe. Palestine: World Tourism Organization.

Table 1. Number of the Palestinian Accommodation in the West Bank (Rooms \& Beds)

Source: The Palestinian Central Bureau of Statistics, the Hotels Survey, Annual Report, (2010)

\begin{tabular}{|l|l|l|l|}
\hline City & Number of Tourist Accommodation & Number of Rooms & Number of Beds \\
\hline Bethlehem & 28 & 1745 & 3599 \\
\hline Ramallah & 18 & 596 & 1619 \\
\hline Jericho & 6 & 378 & 743 \\
\hline Nablus & 6 & 121 & 262 \\
\hline Jenin & 2 & 38 & 58 \\
\hline Hebron & 2 & 102 & 195 \\
\hline
\end{tabular}

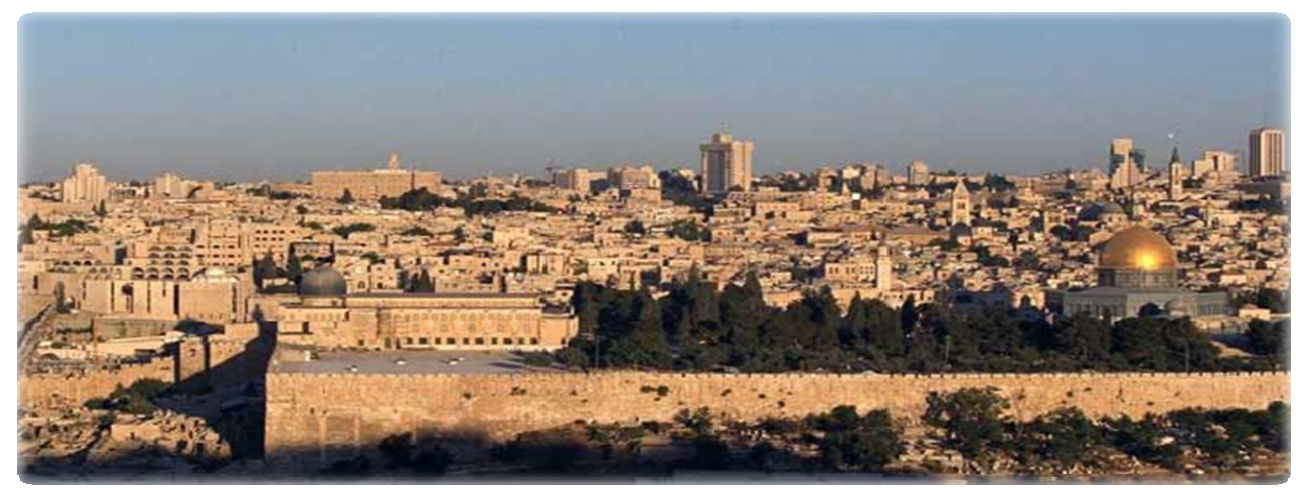

Figure 1. Jerusalem (Al-Quds)

Source: http://www.walkingtojerusalem.org/images/jerusalem.jpg

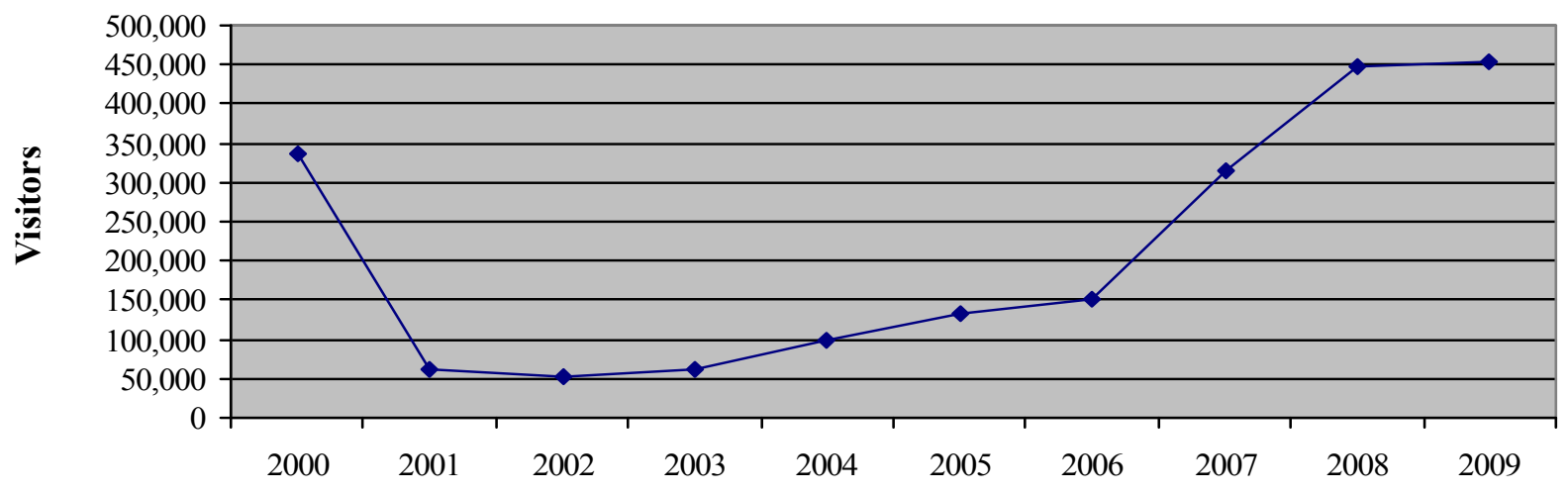

Figure 2. Number of visitors to Palestine from 2000 to 2009

(Source: PCBS, Hotel Activity Survey (2010) 